Notre Dame Law School

NDLScholarship

Journal Articles

Publications

1999

\title{
Retribution and the Secondary Aims of Punishment
}

Gerard V. Bradley

Notre Dame Law School, gerard.v.bradley.16@nd.edu

Follow this and additional works at: https://scholarship.law.nd.edu/law_faculty_scholarship

Part of the Law Enforcement and Corrections Commons

\section{Recommended Citation}

Gerard V. Bradley, Retribution and the Secondary Aims of Punishment, 44 Am. J. Juris. 105 (1999).

Available at: https://scholarship.law.nd.edu/law_faculty_scholarship/852

This Article is brought to you for free and open access by the Publications at NDLScholarship. It has been accepted for inclusion in Journal Articles by an authorized administrator of NDLScholarship. For more information, please contact lawdr@nd.edu. 


\section{RETRIBUTION AND THE SECONDARY AIMS OF PUNISHMENT}

\section{GERARD V. BRADLEY}

Punishing criminals involves more than visiting unwelcome experiencesthe rack, the gallows, confinement, sitting in a corner-upon them. Privations such as these constitute the behavioral substratum, the raw material of punishment. But behaviors such as confinement become the acts that they are, including acts of punishment by confinement, according to the justifying aim(s) which suffuse(s) the behavior. For behaviors such as confinement are ambiguous; limiting another's freedom of movement may be constitutive of a number of different human acts, including quarantine, kidnapping, institutionalization, and imprisonment for crime. Same behavior, different acts. Each of the ends of punishment shapes privations imposed upon criminals into human actions commonly called "punishment."

Or do they all? In Part I of this paper, I defend the view that retribution must be the central aim of a morally justified system of punishment. If retribution is not the central aim, privations imposed upon criminals are scarcely punishment at all. They constitute instead a system of social control or a practice to improve the mental health of some people. The argument in this part is mainly dialectical; retribution makes sense of-explains and morally justifies-some of our system's most cherished practices. Other aims or ends of punishment do not do so nearly as well.

In subsequent parts of the paper, I explore what it means to say that retribution is the central aim of punishment. "Central" does not mean sole or exclusive. There are morally legitimate secondary aims of punishment. The balance of the paper focuses on the relation between and among retribution and legitimate secondary purposes of punishment such as deterrence and rehabilitation. Would a system of punishment be morally sound if it were determined solely by retributive aims? If not, which secondary aims are morally legitimate and why? How should they be integrated into an operating system of punishment? Must these secondary aims be welcome side effects of a sentence determined exclusively by retributive aims? Or do these ends justify adding privations to those justified by retribution, so that the sentence imposed is a composite of two or more aims of punishment?

Retribution explains and justifies many familiar features of our criminal justice system. Retribution explains how the people-the whole community-are the aggrieved party (plaintiff) in all criminal prosecutions; why punishment is due only to those who freely choose to perform unjust acts; 
why imposing privations upon such people does not instrumentalize or demean them and is thus consistent with their basic equality with all other persons in society. Retribution supplies a secure moral justification for our practice of coaxing guilty pleas from the criminally accused by reducing punishment. Finally, though retribution is surely not revenge, it does permit consideration of popular revulsion toward certain types of offenses, as do the federal sentencing guidelines and (I presume) many state authorities.

\section{A. We, the People}

All criminal prosecutions in the United States are carried on by the political community - the People, the State, the Commonwealth-even where criminal acts have specific victims who suffer measurable harm. Do the people act on behalf of the victim? If not, how are all of the people properly seen as the aggrieved party? Why?

To understand this explanatory property of retribution, it is necessary to consider the nature of cooperation in a political society. In the absence of any kind of overarching political order, people in a given place would do whatever they willed. This is not to suppose anything like Hobbes's brutal state of nature, in which nearly everyone would act rapaciously. Quite the opposite. In the absence of political order, some people would act very reasonably, taking into account (we may suppose) the demands of morality as each understood them, along with the predicted reactions of other people. We may even suppose that nearly everyone would act out of regard for what is fair. The important point is that each person would be restrained only by his personal judgment about how best to cooperate with others.

When people enter into political society, they accept an authoritative scheme for structuring their cooperation, thereby excluding other, more or less equally reasonable, alternative schemes. Society's members therefore accept not only limits upon what they may do, but many limits upon their freedom to act upon their own judgments about what is required for successful cooperation. Authorities will specify the pattern of restraint and liberty binding on all. Many laws (as we shall call the directives of public authority) prohibit acts nobody should perform. Many laws select from a range of morally eligible acts and prohibit all of them save one, including acts which, were they selected by authority, would be morally incumbent on all. Driving on the left, or on the right, would do. But having determined that it is to be the right, political authority justly penalizes those who continue to drive on the left. Driving on the left in the United States, is under normal circumstances, immoral. Driving on the right in the United Kingdom is, under normal circumstances, immoral. 
Everyone has a moral obligation to contribute his fair share to the cost of projects which the common good requires. In the absence of an authoritative specification of that fair share, to whom to give it, and how to disburse it, there would be no effective way to pay for and carry out required projects, even where good will prevails. For there are many fair-or at least not unfair -ways of organizing a society's system of exactions for the common good; one must be selected-and enforced-to the exclusion of others if any revenue and appropriations are to be undertaken.

The important thing is that, once authority is up and running, justice requires persons within the relevant jurisdiction to accept the pattern of restraint and liberty authoritatively specified. Persons are under a duty of justice to put aside the liberty which they would enjoy under alternative arrangements, including alternative arrangements not immoral in themselves-arrangements which would be obligatory if they had instead been chosen by authority, and which may be, in some ways, a better arrangement. That is, the authoritative pattern is not binding only, or because, it is in truth the best way. Generally speaking, it is binding because it has been chosen.

Criminal acts often, but not always, involve an injustice to one or more specific persons: the defrauded old lady, the black-eyed assault victim, the hapless and involuntary pedestrian whose car was stolen. But there are some "victimless" crimes, and sometime the whole community is victimized, as in pollution or "quality of life" street offenses like public intoxication. But what always occurs when a crime is committed is this: the criminal unfairly usurps liberty to pursue his own interests and plans, contrary to the common boundaries for doing so marked out by the law. Thus far viewed, the whole community-save the criminal-accepts the constraints specified. The criminal's act of usurpation is unfair to all of them. Punishment aims to restore the order of justice, to put as it were the entire community back on track, aright, with regard to that distribution of liberty, by depriving the criminal of his ill-gotten gain.

Punishment may rightly include an order of restitution or some other act of reparation to the person specifically harmed by the criminal act. The essence of punishment, however, is imposing upon the criminal's will, to make him suffer some deprivation of liberty to do as he pleases, to be entirely the author of his own actions. In doing that, the bold assertion of will which constituted the criminal act is remedied, undone. Viewed over the course of the punishment, the usurpation is effaced; society is eventually restored to a pattern of equality with regard to liberty. Those who take more liberty than the norm allows and more than others take will, finally, be disgorged of their loot. Crime does not pay; observing the law does. 
Someone might wonder how, on this view, are law-abiding members of the community treated unfairly or disadvantaged where the criminal act is malum in se. It is indeed odd to say that, with regard to immoral acts like murder and rape, law-abiding people sacrifice some "liberty" to act on their own judgment. In such cases, is not the only injustice that harm visited by the criminal upon his particular victim?

The victims of rape and murder suffer egregious injustice. But all lawabiding people are harmed, too. They refrain from acts they would otherwise perform, and which they would have good moral reason to perform, because of the laws against rape and murder. But no one who rapes or murders is ever morally justified. If, however, there were no recognized or effective punishing authority, persons would justifiably take steps to protect themselves against threatened assaults, and thus act directly for the common good by punishing criminals. They cede this liberty to public authority. If-when-a crime goes unpunished, people rightly wonder whether the criminal justice system in place should be removed or reformed. The people have, as it were, consigned their liberties to public authority, on condition that public authority effectively punishes criminals.

Besides: there is a great common benefit in maintaining respect for law and fostering the attitude of self-subordination that is essential to the flourishing of any legal order. For these reasons, lawbreaking, as such, harms the common good, and disadvantages every member of society by devaluing a habit or attitude conducive to everyone's well-being. Even where the positive law violated by a criminal prohibits an act which no one else wants to perform (say, an especially repulsive type of sexual misconduct), society suffers by virtue of the damage done to the great, public good of law-abidingness.

We may now see how punishing persons for crimes that involve no injustice to particular person, so-called "victimless" crimes, is morally defensible. For the people are victims of "victimless" crimes the same way they are with other crimes. The essential injustice of criminal acts-the unfair usurpation of liberty-is the same. This injustice may be greater with regard to "victimless" immoralities. It might be the case there that the fact of legal restraint is a weightier reason in law-abiding persons' deliberations than it is where individual victims suffer. The temptation to engage in entirely selfregarding (even if immoral) acts may be great. Certain morals laws-those concerning alcohol, gambling, non-obscene adult books-prohibit acts which are not, in themselves immoral. The reason for blanket legal prohibitions (where it is the case) of drinking or gambling is concern for the character of the morally weak. A culture stripped of certain temptations helps the weak to be good. The morally strong abstain from acts which are, for them, morally worthwhile or at least morally harmless. They abstain precisely as a sacrifice 
for their immature fellows. Simply put, morals laws are often brute restraints of the morally mature. Persons who claim the liberty to indulge alcohol, gambling, or adult books make a mockery of that sacrifice.

\section{B. Protecting the Innocent}

The most important moral signature of retribution is its exceptionless protection of the innocent from conviction. Where retribution is the justifying aim of punishment, unjust acts, and nothing else, are subject to punishment. Uncharitable attitudes, character defects, and personality disorders which might call forth intervention in a rehabilitative or reformative regime of punishment are not punishable. None of these is an act. None of these is an unfair appropriation of liberty. Proponents of rehabilitations and paternalistic moral reformers are hardly able to explain why their particular ministrations must await the performance of some prohibited act.

William O. Douglas, I believe, once said that it is better for a hundred guilty persons to go free than for one innocent person to be punished. Maybe. The precise level of exertion morally required to avoid convicting the innocent is a matter of legitimate debate. Retribution by itself is compatible with various levels of effort. There can be no question, though, that where retribution governs criminal justice, punishing an innocent is never knowingly to be done.

This absolute prohibition upon knowingly punishing the innocent is easy to explain: it is an implication of the retributive justification for the punishment of anyone. Where there has been no disturbance of the pattern of equilibrium, there is no disorder to be remedied, no order of justice to be restored. It is, in reality, impossible to knowingly "punish" an innocent person, as it is impossible to knowingly trick yourself. "Punishing" $\mathrm{X}$, who happens to be available and is powerless to defend himself, for a crime committed by someone else may satisfy the desires of some people for atonement, people who either believe $\mathrm{X}$ is guilty or do not care whether he is guilty or not. But no one in the know can honestly believe that the order of justice has been restored. In reality, they cannot but think that the order has further been disrupted by their oppressive imposition upon the hapless $X$.

H. L. A. Hart famously struggled with the question of punishing the innocent. ${ }^{1}$ Hart's view of punishment was a decidedly utilitarian one: a regime of punishment was justified by its good consequences for society. On the last day of society, Hart stated, there would be no point in punishing anyone.

1. H. L. A. Hart, "Murder and the Principles of Punishment," in Punishment and Responsibility: Essays in the Philosophy of Law (Oxford: Oxford University Press, 1968). 
Hart distinguished justification of the general practice of punishment from the question of eligibility of specific individuals for punishment. To protect innocent individuals, he said that a stipulation could be made that one must not be punished, save for violating the law. But Hart added: "No doubt this recognition of the individual's claim not to be sacrificed ... is not absolute. Given enough misery to be avoided by the sacrifice of an innocent person, there may be situations in which it might be morally permissible to take this step."2

For Hart, the whole regime of punishment is justified by the good which is done for people when arbitrary intrusions and losses, including all physical assaults-by criminals and by police-are kept to a minimum. He said that it would hardly comport with this aim if those responsible for keeping criminals at bay were themselves unleashed; that is, if the police-more than very rarely -arrested an innocent person and instigated his conviction. If such an injustice occurred with any regularity, the people would be insecure due to the specter of police misconduct, just as they are where crime goes unchecked by the police. So, Hart's defense against the charge that his utilitarianism could result in oppression was his speculation that the total number of privations will be lowest where innocents are almost immune from punishment.

Does Hart's speculation succeed as a response to the charge? The lengthy response which Hart's position calls for is beyond the scope of this paper. But there appears to be some naivete in Hart's speculation, perhaps even a rosy optimism. If so, his position is considerably weakened, for his position depends for its soundness upon real-world results, not upon analytical clarity or the logic of a deductive argument. Will, in fact, the total number of arbitrary intrusions-crimes and unjustified police conduct-be least where the innocent are treated as (virtually) sacrosanct, at least insofar as the intentions of authorities are concerned? It seems doubtful. For one thing, the most important determinant of crime is probably the culture of a given society. Where persons are by habit and belief disposed to observe the law, little crime occurs and few police are needed. Hart's speculation would have to be tested in a less orderly society, one where many residents were disposed to commit crime but do so-or not-depending upon police activity. In other words, Hart's speculation suffers from the limitations which ail utilitarian analyses of crime control. But, assuming a more or less tight correlation between police conduct and the incidence of crime, is it likely that treating the innocent as, for practical purposes, immune from intrusion keeps crime rates down? Our society (more or less) treats the innocent as immune from police

2. Ibid., 81. 
intrusion; at least, articulable, judicially reviewable cause is necessary for police to accost an individual. But our devotion to such constitutional principles as "probable cause" is scarcely thought to be, by itself, an effective crime-control technique. Letting "a hundred guilty go free" to forestall convicting one innocent is a sure way to increase the overall incidence of crime. Less scrupulous regimes, moreover, seem able to practically eliminate crime by, among other methods, cowering citizens through occasional "punishment" of innocent persons. Experience suggests, at least, that concern for the innocent, just by itself, encourages crime.

Hart leaves aside an important moral question, too. He allows that the occasional sacrifice of an innocent might be fortified by a utilitarian crimecontrol strategy. Very well. But on what basis is this or that person chosen as the sacrificial lamb? Even on Hart's terms, the fairness of one's conscription into a project for the common good is a pertinent question. Hart does not address it. He might have in mind a truly random impressment. If so, and granting his other contentions, randomness might be a fair method of selection. (During the Vietnam War, being drafted depended on a random draw of birthdays. That lottery system was, under the circumstances, probably the fairest method of selecting young men to fight the war.) But a truly random pickup and prosecution of an innocent has little utility in the real world. Scapegoating may, indeed, promise the pacification of a restless population. It may be-often it is-a means of keeping at bay a particular minority, racial, or ethnic group. But selective or targeted "scape-goating" is not random; it is not fair.

\section{Plea Bargaining}

Retribution provides a cogent defense of the morality of plea bargaining, that practice in which the criminally accused pleads guilty as a result of sentencing concessions offered by the prosecution and ratified by the judge. That retribution should offer a defense of the morality of plea bargaining may surprise. After all, the criminal's usurpation of liberty-and thus, the presumptive scope of the corresponding punishment-would seem to be settled when the crime was done. How, under a retributive view, is the criminal's punishment properly mitigated by his willingness-much later, at a different place, and entirely apart from any compensation to his victim-to forego a trial, and plead guilty instead?

Some secondary aims of punishment provide good explanations for plea bargaining. The pleading defendant is on the path of moral reform. The federal sentencing guidelines, for example, give the pleading defendant credit 
for "accepting responsibility." 3 On the rehabilitative or therapeutic view of punishment, there is room for concessions to the pleading defendant, even if the acceptance of responsibility (impliedly the basis of the concession) does not accord with the presuppositions of the therapeutic model.

The pleading defendant, by accepting responsibility for his crimes (that is, by admitting his guilt and submitting without further protest to punishment), earns some relief from the deterrent component of sentencing, at least that aspect called "specific deterrence." Specific deterrence is basically an admonition to this defendant that crime does not pay. By pleading and accepting his punishment, the defendant indicates his assent to that proposition.

Thus: specific deterrence and moral reform-two of the secondary aims of punishment-are favorably served by the pleading defendant. If these ends are proper elements in figuring the precise terms of a particular sentence, as I think they are, then the pleading defendant would be treated unfairly if he received the same sentence as someone otherwise like him who was convicted after trial.

The pleading defendant also acts directly for the benefit of many individuals. In so doing, he further evidences a changing character-a change for the better. He relieves witnesses of a duty to testify, especially where a witness is subject to humiliation (a victim of sexual misconduct), abuse (a robbery victim aggressively cross-examined), or even danger (testifying against the mob chieftain). Often his punishment includes some act (restitution, for example) which directly benefits, if it does not make whole, his victim. The collateral effect of the criminal conviction is to reduce any parallel civil action to a hearing on damages. In many cases, the defendant's plea eliminates the temptation that full-dress trials present to many participants to act unethically: the defense lawyer face no dilemmas about perjured testimony; witnesses are not tempted to perjure themselves. This temptation is often as great for police witnesses against the defendant as it is for, say, alibi witnesses he might summon to help exculpate him.

The pleading defendant also promotes the common good, and here is where retributive considerations warrant a reduced sentence. The criminal justice system-the vast institutional apparatus centered on the courthouse, populated by lawyers, judges, and probation officers and attended by police officers, lab technicians, coroners, and civilian witnesses-is a vastly expensive, scarce community resource. (I do not here refer to the corrections system or to the lawmaking activities which create and sustain a system of crime and punishment.) This scarce resource is created by the community for the limited

3. United States Sentencing Guidelines, § 3E1.1 (1998). 
but important purpose of fairly and accurately adjudicating accusations of criminal misconduct. Since it is a scarce resource, duties of fairness in its utilization arise: all those who have a say in how this scarce resource is used-including the criminal defendant-have moral duties concerning its use. It makes no practical difference that one thinks the system is understaffed and underfunded. Duties of fairness arise, like it or not, from the fixed quantity of resources available, no matter what the quantity is.

This duty of fairness runs first of all to other defendants, especially to those for whom trials are morally necessary-innocent defendants. But even other defendants who are inclined to plead guilty have significant needs for the attention of defense counsel, prosecutors, judges, and other court personnel. The capacity of these persons to give other pleading defendants the attention they deserve is limited by the number of cases tried. In the time it takes to try one felony, perhaps dozens of plea negotiations can be conducted.

The defendant has the legal liberty to plead not guilty, to force the political community to prove its case against him, and thus to subject various individuals to greater or lesser inconvenience. The defendant is neither obliged to explain his plea of not guilty nor is he informed that he faces adverse legal consequences by pleading not guilty. The defendant, in other words, is not only at liberty to command the consumption of a scarce common resource by dint of his saying so. His saying so effectively imposes detriments (of various sorts) upon many innocent individuals.

The accused is also at liberty to act for the benefit of others, considered both individually and as constitutive members of political society. If he pleads guilty, he permits the scarce resources he would otherwise consume to be devoted to the causes of others who might have cases more deserving of trial, or who have other reasonable claims upon their attention. By freeing all the institutional actors concerned with his case-his lawyer, the judge, the prosecutor, police witnesses-to tend to other duties of various sorts, the pleading defendant acts indirectly, but effectively, for the benefit of the whole community. In this manner, the pleading defendant anticipates some of his punishment. He gives back to the community a scarce resource-a share of the capacity of the criminal justice system-and thereby diminishes the disequilibrium he created by usurping another scarce resource.

\section{Retribution and Popular Beliefs}

The United States Congress, in setting up the Federal Sentencing Commission, included as criteria for sentencing "the community view of the gravity of the offense" and "the public concern generated by the offense." A

4. 28 U.S.C. $\$ 994(c)$. 
retributive approach to punishment does not aspire to quell popular outrage; it is not a conduit for popular revulsion. Retribution is not revenge. Retribution is nevertheless compatible with the congressional directive.

To recognize the relevance of popular concern is not to cater supinely to the mob, as Pilate did in releasing Barabbas. There is no question of offering up the innocent to satiate a popular prejudice or bloodlust. There is no necessary implication of what I call "Devlinism," that type of deep conservatism about principles of social cohesion which was at the heart of Lord Devlin's position in his debate with H. L. A. Hart. Devlin was prepared to make crimes out of offenses against the popular morality, whatever that morality happened to be. Nothing in recognizing the community's evaluation of the gravity of an offense implies that an offense may be defined without regard for the moral truth of the matter. ${ }^{5}$

How may the congressional expressions of popular concern be relevant to sentencing within a system centrally determined by retribution? The essence of a criminal act is the criminal's unfair appropriation of liberty. The "unfairness" arises against a baseline of law-abidingness; that is the stance of the community, the public. But what is the measure of a criminal's unfair self-preference? Once the harm to be redressed is seen to be not the injury or loss to specific individual victims, but the usurpation of liberty, the proper type and quantity of punishment is, it seems to me, properly shaped by various indicia. Given what punishment aims to do-to restore harmonious cooperation among freely choosing persons, so that over the long haul none is foolish for observing the law-the degree to which law-observing people consider themselves disadvantaged is relevant to sentencing.

Put another way: unfaimess is a relational term. Sentencing authorities must take into account the interests of both the criminal and the people. Since there is no transsocial (that is, abstract, universally or unconditionally correct) metric for punishments, the morally correct measure of punishment depends upon the extent of unfairness, and that has something to do with how the community feels.

\section{II}

The centrality of retribution to understanding punishment does not mean that retribution includes premises which lead, by deduction or by compelling inference, to specific forms and degrees of punishment for particular offenses. Quite the contrary is the case: retribution as the justifying aim of punishment

5. In this connection, see Robert P. George, "Social Cohesion and the Legal Enforcement of Morals: A Reconsideration of the Hart-Devlin Debate," in Making Men Moral: Civil Liberties and Public Morality (Oxford: Clarendon Press, 1993). 
does not dictate any specific form or degree of punishment. Even if retribution were the sole aim of punishment, sentences imposed upon convicted criminals would vary from place to place. They would depend upon the free choices of those responsible for design and administration of the criminal justice system, and would rightly reflect, to some extent, the customs of the local population. Robbers in a particular jurisdiction might get ten years and tax cheats pay a million-dollar fine. In another jurisdiction, they might each get hard labor, and in a third place, the tax cheat might be punished more severely than the street thief. Retribution does require, however, that sentences within a jurisdiction exhibit a rough proportionality, with the most extravagant usurpations of liberty being punished similarly and more severely than modest usurpations.

No sentencing regime operates solely with reference to retribution. The regime Americans inhabited from around 1965 until sometime in the 1980s, for example, was heavily influenced by rehabilitative ideals. The prototypical sentence was then an indeterminate "one-to-whatever-number-of-years," with a prisoner's actual release date to be decided by a parole board judging his progress toward rehabilitation. Although such a sentence was probably unjust, some consideration of rehabilitation, as a secondary aim of punishment, is not. Let me explain why.

One incident of any custodial sentence is the state's assumption of a paternalistic role concerning the offender, a role which would be wrong outside prison. Prisoners cannot make many decisions for themselves. Their commercial options are those which the prison makes available to them. Their personal choices are limited by the exigencies of maintaining security in the prison. A prisoner with a drug habit may be obliged to seek treatment, both for his own good and for the sake of those living with him in prison. A man guilty of criminal assault may be filled with abnormal rage and required to attend anger-management sessions in jail, or perhaps even in lieu of jail.

The criminal justice system may not establish its hold on anyone who has not been properly ascertained to be deserving of punishment. But of that very large class of eligible persons, the system may burden some more than it otherwise would in order to give them the help they need. So long as these burdens do not burden him much more than they benefit him-and so long as the criminal is not being burdened solely for the benefit of others-no unfairness to him arises. The sentenced prisoner's overall welfare is part of the larger society's common good. It serves the common good, therefore, to attend to the prisoner's well-being, and not only with a view to his improved behavior once he is released and restored to society with the law-abiding.

Sentencing patterns in America outside the juvenile justice system are no longer much influenced by a rehabilitative theory of punishment. The federal 
sentencing guidelines reject rehabilitation as an end or goal of punishment. ${ }^{6}$ Being "tough on crime," which is to say, being very tough in sentencing convicted criminals, is now the common aim of both major political parties. This seismic swing in moral aspirations and in policy decisions is reflected in the staggering number of inmates in our prisons. The public enthusiastically supports long terms of imprisonment, even if it is reluctant, though not wholly unwilling, to tax itself for the necessary prison and jail construction.

Congressional legislation setting up the Sentencing Commission states that the Commissioners "shall" consider, among other factors, "the deterrent effect ... [upon] others" and "the current incidence of the offense" in establishing guidelines. ${ }^{7}$ The Commissioners (who were responsible for producing the guidelines which now govern sentencing in federal courts) did so, especially regarding recidivists. They said, in their commentary on the relevance of a defendant's criminal history to sentencing, that "[g]eneral deterrence of criminal conduct dictates that a clear message be sent to society that repeated criminal behavior will aggravate the need for punishment with each recurrence." "A defendant with a record of prior criminal behavior is more culpable than a first offender and thus deserving of greater punishment."

Are these morally legitimate, if secondary, aims of punishment? If so, why? And how can these considerations be integrated with the system's central retributive aim?

I should like to deal with the "specific" element first, and then the "deterrent" effect.

Sentencing patterns of repeat offenders seem at odds with retribution. It would seem that the injustice of, say, felony forgery-the demonstrated preference for one's own liberty, the disruption to the order of justice, and the extent of private harm caused-is scarcely dependent upon the prior criminal acts, if any, of the forgerer. Yet in a standard case, the sentence for a person's initial conviction for passing a bad check would be probation, a second offense would result in short jail time, and a third would call forth a sentence of imprisonment comparable in length to that for manslaughter. How is this pattern of predicate offenses and recidivist sentencing, a mainstay of our regime, related to the retributive view of punishment?

The federal Commissioners opined that the repeat offender is "more culpable." They did not mean "more culpable" as a judgment of the instant criminal act or of the malice expressed by and through it. "More culpable"

6. 28 U.S.C. $\$ 994(k)$.

7. 28 U.S.C. $\$ 994(c)$.

8. United States Sentencing Guidelines, chapter four ("Criminal History and Criminal Livelihood"), "Introductory Commentary."

9. Ibid. 
was some judgment about the defendant's will in general, his character. A chronic offender shows himself to be incorrigible; his will is permanently, more or less dangerously (depending upon the type of habitually chosen crime), opposed to the interests of others. The habitual offender has shown himself to be impervious to deterrence. He was not deterred by earlier, lighter sentences.

Are such progressively harsher penalties for the same offense, by the same offender, explainable by retributive considerations? If not, are they justified by legitimate secondary considerations?

Let us take a look at the earlier sentences first. They are probably best viewed as exercises in leniency, departures down from an (otherwise) appropriate sentence. The initial sentencing judge might reasonably decide that exposing an initiate to the bad influences of prison would confirm the offender in his criminal leanings, so that further crimes, and the future costs and trouble of incarcerating him, would be all but certain. Or perhaps jail space is at a premium; available space is reserved for hardened criminals. "Taking a chance" on leniency is arguably a prudent risk, one worth running not as a favor to the offender but as a service to the community. The community benefits from steering persons away from a life of crime, more than it does coping (even effectively) with the ill effects of such a life. Sometimes the effort to save the initiate is more rather than less severe. Some forms of "shock" sentencing are designed to scare the apprentice out of the life, by showing him what paying the price involves.

Where the will is not yet finally and fully committed to injustice, does retribution permit leniency? Yes. But even if not, is leniency appropriate? Yes. Leniency works no unfairness to the offender. No question of using or demeaning him arises. The specific victims of the crime are not treated unfairly; it is not the aim of the system to vindicate their individual interests. As members of the political community, the victims share in the good effects which are thought to justify leniency. And the community benefits, in ways noted in the preceding paragraph, by the prudent exercise of leniency.

What of the far end of the recidivist scale? Do retributivist considerations justify life imprisonment of a three-time loser, where a young first offender might get a noncustodial sentence?

No. The recidivist sentencing schemes so common today must be seen as a progression of tests or obstacles which the maturing offender passes on his way to a status something like, "BEWARE: Dangerous individual; If at liberty, will prey on people!" The long sentences are intended by public authority to warehouse the chronic criminal until his energy for serious criminal misbehavior has run out. Note well: these sentences are not being considered for their deterrent effect, if any they have, upon other two-time 
losers. Specific "deterrence" is not quite an apt description either. The apt comparison is to now unfamiliar, but once common, sentences of exile or transportation. The question is not whether retribution as such justifies such long sentences-tantamount to banishment-but whether these sentences are morally justifiable.

Public authority is morally justified in expelling inveterate criminal offenders as a matter of common defense, where there is no other way to protect law-abiding people from them. Certainly, a career criminal of the type we are imagining would rightly be denied permission to emigrate from another country. If he were here, but deportable, he would surely be deported. Effective banishment through incarceration would seem to be justified as well. Is banishing such miscreants a matter of punishing them? Yes and no. Yes, in that banishment is an unwelcome imposition upon one deserving of harsh treatment, an imposition which serves the community's common good. No, in that the "sentence" is at least partly non-reparative. The sentence is partly a preemptive act of communal self-defense. The predicate, one might say, of this morally upright defensive act is the whole criminal history of the candidate for banishment.

The integrity of procedures relied upon for such a serious decision is an important question. There is reason to be wary, morally speaking, of the very long sentences-of "warehousing"-that are now common. There is reason to wonder whether the human dignity of some long-term prisoners has been forgotten or implicitly denied. There is reason to question whether this or that statutory sequence is a genuinely reasonable ground for judging anyone to be incorrigible, a fit candidate for banishment. But the act of banishment, just as such, occasioned by a reliable finding of career criminality, is morally permissible. Indeed, with regard to certain chronic violent offenders, public authority is probably under a duty to banish — "warehouse" - them by lengthy incarceration.

\section{III}

The central point of sentencing criminals is to restore the order of justice disturbed to the extent of the criminal's unfair appropriation of liberty. The point of the restoration is to ensure that over a period of time, a fair pattern of restraint and liberty is maintained across society, so that being law-abiding does not work to one's disadvantage.

There is ambiguity within retribution about the proper measure of punishment. It is time to address that ambiguity. Is the measure limited to the disturbance created by this or that discrete criminal act, or is it some proportionate share of all the privations necessary to bring society, in the long 
run, into a state of fair equilibrium? Is the sentence for, say, this robbery to be the same regardless of whether the defendant is the only one of a hundred robbers to be apprehended, or one of ninety-eight to be apprehended? Even in an ideal society, one in which every criminal act is punished, there would still be "transaction costs" to be recovered. These costs include, but are not limited to, impositions upon law-abiding people to serve as jurors, witnesses, underpaid prosecutors, and defense lawyers. The community must underwrite the vast apparatus we call the (criminal justice) "option." In an ideal society, then, sentences should, according to the established metric, slightly exceed the criminal's selfish appropriation. Such a "surtax" would genuinely restore the equilibrium disturbed by crime and its transaction costs.

None of us lives in an ideal society. In any real society, there is a significant asymmetry between the amount of crime and the number of criminal acts successfully prosecuted. The liability side of the ledger is much greater than the assets amassed by punishing the criminals who are caught and successfully prosecuted. How are we to choose between a permanent deficit, and making the extent of punishment a function of total crime divided by number of criminals convicted? What if rather few criminals are convicted?

We may now also see that retribution has an odd, even paradoxical, relation to the political common good. The common good calls unequivocally for less rather than more crime. That there be virtually no crime at all is the desideratum; very few criminal acts may be said, in a basically just society, to have any positive value. But no society is completely just, and some morally justifiable civil disobedience, for example, is probably to be expected in any real society. And there may be some very low-level criminal misbehavior which is the product of the inherent limitations of drafting statutes and police discretion. For example, persons may reasonably conclude from a longstanding lack of enforcement that a statute prohibiting moderate beer drinking in a public park is no longer the law. Yet a police campaign against it, so long as the statute has not been repealed, may be justified.

Almost any crime does unalloyed damage to the common good, and usually does harm, sometimes great harm, to particular members of the society. Retribution, however, has no magnetic bearing upon the amount of crime in a society; it swings free of crime-control concerns. This is not to say that the retributive point of view has no tendency to reduce crime. Its aspiration to deprive the criminal of his unjustified self-preference amounts to a "crime does not pay" platform, or a certain understanding of what that means. Still, the retributivist is forward-looking in the limited sense of bringing into being a fair distribution of liberty, to straighten out accounts in the long run. Its aim is to restore a simulacrum of the status quo ante. Retribution is, by itself, not a complete crime-control strategy. 
Let me put it plainly. In a society like ours, where 1.8 million people are incarcerated, the scales of the retributivist may be balanced. Perhaps those millions represent the vast bulk of these who have broken the criminal law. They are in the process of restoring the order of justice disrupted by their acts. But is such a society flourishing? Hardly. Those incarcerated have exceedingly dim prospects for becoming and doing good. Their specific victims, who might well number in the many millions, have suffered disruption in their expectations of security, of their life plans. How many more people in the society are diminished by the fear of crime?

Deterrence aims to more directly discourage crime. It may not work, or it may not work well, or it may not work as its designers intended. But if there is evidence that it works, is general deterrence-setting an example for many others by the treatment of this one-morally legitimate? Is it the case that one is limited to welcoming the deterrent effects-which may be considered - of sentences which are the product of retributivist reflections? Is it wrong, in other words, to add to a sentence precisely to deter? Is adding to a sentence determined by retributivist considerations wrong because to do so is to demean the one being punished, to use him, to manipulate him as a thing or instrument for the benefit of the group?

I think it is not, on this condition: we must put aside any intentional harm to a fundamental aspect of human flourishing, such as life or health. To directly attack these goods is to act immorally. One way of describing that immorality is to say that one treats the other as a means to one's end. Sentences must be limited, under this condition, to deprivation of instrumental goods-money, liberty - and to discomfort. So, intentional infliction of pain may be an appropriate sentence, but mutilation is not. Pain is transient and surely qualifies as an unwelcome imposition; mutilation involves disfiguring the body and impairment of function. Mutilation is an act which directly attacks the basic good of bodily health.

I propose to treat the matter conceptually, and not semantically or mathematically. Whether deterrence is permissible is not to be resolved by massaging the meaning of the proposition, "retribution is the central or justifying end of punishment." Nor do terms of years or dollars in fines have anything to do with it. The question is not whether to add a year or a dollar, but whether aiming at deterrence at all is permissible: Is it a good reason to add anything to a sentence?

Here is the argument that the aims of deterrence may justify an increased sentence, and that it is not unfair to set a sentence in light of the need to deter others.

1. The criminal law itself - the ligament of society, the settled way for just cooperation among freely choosing and acting persons-is itself a common 
good, a valuable social institution which serves everybody, including those who sometimes violate those laws.

2. Public authority is morally justified in taxing and otherwise burdening the members of society in order to maintain this system, just as it is justified in imposing burdens to create or maintain other valuable resources and institutions from which everybody benefits, even if everyone does not benefit in the same way or precisely to the same extent. Society's members benefit unevenly from our system of free public schools, and from state-maintained highways. Some people, notably the Amish, not only benefit little from such public undertakings, they also believe that is not the business of government to engage in these activities at all. Even so, if there is in truth a genuine common good in education or transportation, everyone may fairly be made to bear a proportionate share of the costs, notwithstanding conscientious objections.

3. The burdens of sustaining projects necessary for the common good need not be equally shared to be fairly shared. A first example: eminent domain. Public authority determines that a highway is necessary for the common good. Persons owning property along its way are forced to sell. They are not accorded the freedom of choice that other homeowners enjoy, and which they would enjoy against the rest of the world. And they must sell at a Fair Market Price, which is not what any buyer would pay, but what the average buyer would pay. So, a widow living with her memories on the old farm must move despite her priceless sentimental attachment to the place; that her home has some idiosyncratically appealing features, or features which were desirable years ago but which are now not valued by most buyers, does not figure in the sale price. Only certain classes of people are called for jury duty. The public has a right to everyone's evidence. Upon whom this burden of giving testimony falls is a matter of happenstance. Society's members bear very unevenly the impositions which are a corollary of normal police work. Residents of certain neighborhoods or members of certain racial or ethnic groups suffer intrusion by the police more than others. This may be a defensible effect of proper police attention to high-volume call areas or to established demographic patterns of criminal activity by certain groups.

Some larger examples. The wealthy probably benefit less than most people from a system of public schools and may be able to insulate themselves from crime by use of their own resources. But they are fairly taxed to pay for courts and police and schools, while others, perhaps more dependent upon public services, fairly pay nothing.

Finally, the whole society benefits from an effective national defense. Yet only the able-bodied young are required to serve in the military. Many who wish to serve are turned away for minor deficiencies. 
4. It plainly serves the common good that there be relatively less-in absolute terms, very little, almost none-crime than more.

5. There is a special burden which arises from the project of crime control. It is not taxes and jury duty, but other privations which-if the presuppositions about human psychology and behavior implicit in the deterrence argument are true-when added to a sentence, would give us less rather than more crime. It is that "add-on" to sentences which represents deterrence considerations.

6. The class of persons eligible to bear this burden is the class of persons convicted of crimes. They stand in relation to the common good of relative crimelessness as young able-bodied men do to national defense. Is it fair to impose this burden of supporting the common good upon the class of convicted criminals?

Yes, with this absolutely essential modifier. Public authority is under a stringent duty of faimess, consistent with respecting human rights and with discharge only of their other most basic responsibilities, to avoid having to impose unevenly upon the class of prisoners. That is, public authority must take all feasible steps to avoid a crime-control policy which relies heavily upon extended incarceration. An example: it would be unfair to rely upon the occasional death sentence (assuming it is not otherwise immoral) to deter criminals, or to invest nothing in probation or juvenile services and then warehouse young men until they pass their fiftieth birthday.

With this crucial condition, it is fair to impose upon members of the class uniquely positioned to make a necessary sacrifice.

Prisoners are members of the political society. Despite their punishment, they are not outcasts or aliens. They continue to enjoy the benefits of the law and of political society. They are maintained by the state. The law guarantees them many rights, and it protects them against certain forms of arbitrary treatment by their custodians. Much less effectively, the criminal law protects them against the depredations of other inmates. Prisoners are unable to contribute to the common good in many ways. They may be made fairly to contribute in ways they can, by sacrificing some measure of autonomy to the common good of crime control.

\section{IV}

Retribution is the central moral account of what we are doing when we punish criminals. It is not, however, an overriding principle of action by public authority. It is not a self-contained module, to be fit into the big scheme of things, operating autonomously by its own compass bearings. Its operation is limited and permeated by the common good of political society. Were it 
otherwise, retribution would be more than the justifying and central aim of a system of punishment; it would be the only important principle of that system. It is not.

A system of punishment determined solely by retributive aims would not serve the common good of society. It might not be unfair to those criminals punished, but it would be an injustice to those who observe the law. The overarching common good includes the leading secondary aims of punishment: deterrence (specific and general) and rehabilitation. By constant reference to the common good, especially to the principle of faimess to criminals, their victims, and the community, these secondary aims can be integrated into a system of punishment centrally determined by retribution. 
